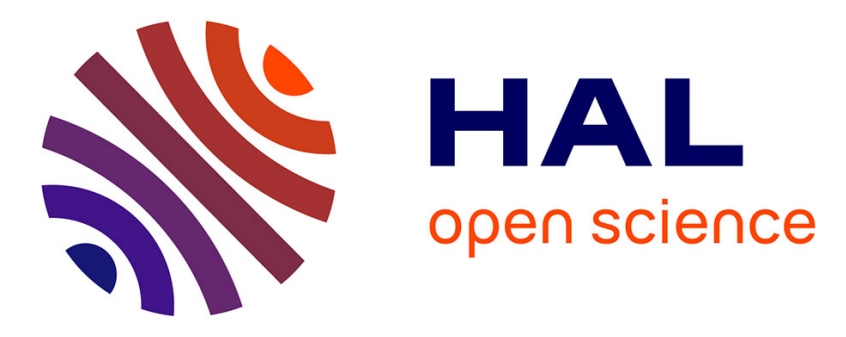

\title{
A simple gas pressure manometer for measuring hydrogen production by hydrogenogenic cultures in serum bottles
}

Hana Gannoun, Lamia Ben Gaida, Rafika Saidi, Baligh Miladi, Moktar Hamdi, Hassib Bouallagui, Pierre-Pol Liebgott, Richard Auria

\section{To cite this version:}

Hana Gannoun, Lamia Ben Gaida, Rafika Saidi, Baligh Miladi, Moktar Hamdi, et al.. A simple gas pressure manometer for measuring hydrogen production by hydrogenogenic cultures in serum bottles. Process Biochemistry, 2018, 65, pp.157-163. 10.1016/j.procbio.2017.10.011 . hal-01629103

\section{HAL Id: hal-01629103 \\ https://hal-amu.archives-ouvertes.fr/hal-01629103}

Submitted on 8 Feb 2019

HAL is a multi-disciplinary open access archive for the deposit and dissemination of scientific research documents, whether they are published or not. The documents may come from teaching and research institutions in France or abroad, or from public or private research centers.
L'archive ouverte pluridisciplinaire HAL, est destinée au dépôt et à la diffusion de documents scientifiques de niveau recherche, publiés ou non, émanant des établissements d'enseignement et de recherche français ou étrangers, des laboratoires publics ou privés. 


\section{A simple gas pressure manometer for measuring hydrogen production by hydrogenogenic cultures in serum bottles}

Hana Gannoun ${ }^{\mathrm{a}, \mathrm{b}}$, Lamia Ben Gaida ${ }^{\mathrm{a}, \mathrm{b}}$, Rafika Saidi ${ }^{\mathrm{a}}$, Baligh Miladi ${ }^{\mathrm{a}}$, Moktar Hamdi ${ }^{\mathrm{a}}$, Hassib Bouallagui ${ }^{\mathrm{a}}$, Pierre Pol Liebgott ${ }^{\mathrm{c}}$ and Richard Auria ${ }^{\mathrm{c}, *}$

${ }^{a}$ Université de Carthage, Laboratoire d'Ecologie et de Technologie Microbienne, INSAT, B.P. 676, 1080 Tunis, Tunisia

${ }^{\mathrm{b}}$ Université de Tunis El Manar, ISSBAT, 9 Avenue Zouhaïer Essafi, 1006 Tunis, Tunisia

c Aix Marseille Université, CNRS, Université de Toulon, IRD, MIO UM 110, 13288 Marseille, France

*For correspondence: e-mail richard.auria @ mio.osupytheas.fr ; Tel: 0486090616

Graphical abstract
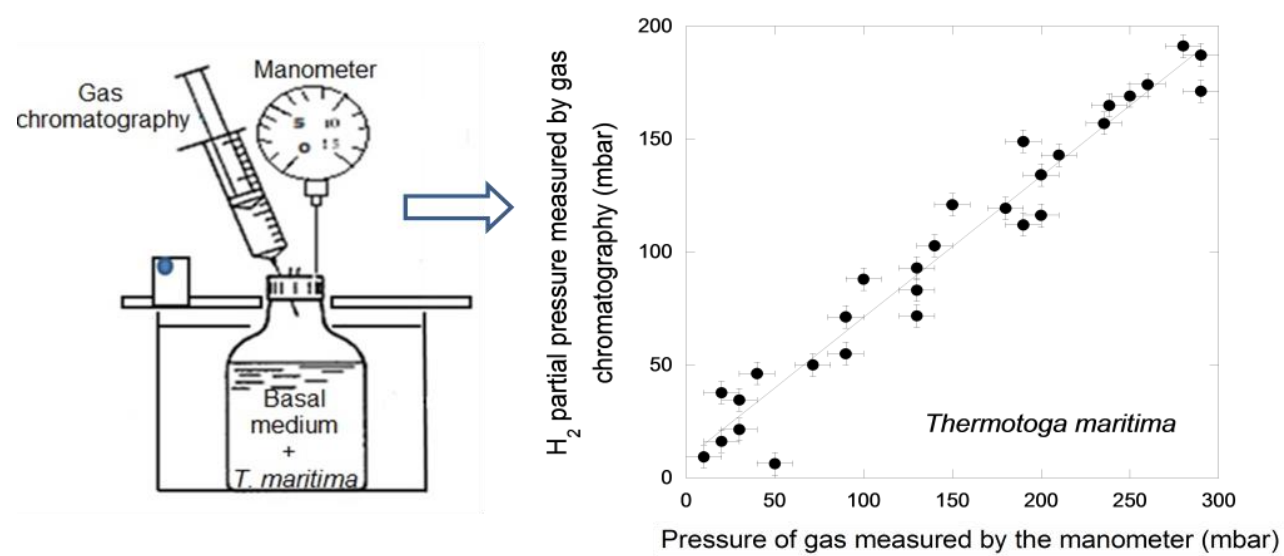


\title{
HIGHLIGHTS
}

- The hydrogen producing capacities of Thermotoga maritima, Thermococcus kodakarensis and Enterobacter cloacae were studied in 116 mL-serum-bottle.

- A linear relationship was established between the partial pressure of $\mathrm{H}_{2}$ and the sum of the partial pressures of $\mathrm{H}_{2}$ and $\mathrm{CO}_{2}$ of each microorganisms.

- Under some assumptions, determination of $\mathrm{H}_{2}$ partial pressure was achievable using a simple manometer.

\begin{abstract}
This study investigated the determination of hydrogen production by three $\mathrm{H}_{2}$-producing microorganisms (Thermotoga maritima, Thermococcus kodakarensis KOD1 and Enterobacter cloacae) cultured in 116-mL serum bottles. A gas pressure manometer was used to measure total pressure in the serum-bottle headspace. It was demonstrated that total pressure is the sum of the saturation pressure of water, the pressure expansion of gases, and the partial pressures of $\mathrm{H}_{2}\left(\mathrm{P}_{\mathrm{gH}_{2}}\right)$ and $\mathrm{CO}_{2}\left(\mathrm{P}_{\mathrm{gCO}_{2}}\right)$. A linear relationship was established between the partial pressure of $\mathrm{H}_{2}$ measured by gas chromatography and the sum of the partial pressures of $\mathrm{H}_{2}$ and $\mathrm{CO}_{2}$ measured by the manometer. When $\mathrm{pH}$ of culture medium was not controlled ( $\mathrm{pH}$ decreased from 7 to 5), the $\mathrm{P}_{\mathrm{gH}_{2}} / \mathrm{P}_{\mathrm{gCO}_{2}}$ ratio was close to stoichiometric $\mathrm{H}_{2} / \mathrm{CO}_{2}$ yield ratio of the most plausible metabolic pathways of each strain. $\mathrm{P}_{\mathrm{gH}_{2}} / \mathrm{P}_{\mathrm{gCO}_{2}}$ values were $1.7,1.9$ and 0.9 for T. maritima, T. kodakarensis and E. cloacae, respectively. In these experimental conditions, $\mathrm{P}_{\mathrm{gH}_{2}}$ can be deduced from total pressure measured by manometer.
\end{abstract}

Keywords: hydrogen, total pressure, manometer, hydrogenogenic microorganisms 


\section{Introduction}

Rising worldwide energy consumption needs, diminishing fossil fuel reserves, and environmentally damaging carbon dioxide emissions from the combustion of hydrocarbon fuels are driving efforts to develop alternative sustainable energy sources. Hydrogen is considered as viable alternative fuel of the future, it is clean and renewable with no $\mathrm{CO}_{2}$ emissions, and can be produced through different methods (biophotolysis, photofermentation, or dark fermentation) from organic biomass using aerobic anaerobic bacteria [1-3]. Dark fermentation (DF) is currently considered the most promising technology as it is an economically advantageous process capable of achieving high hydrogen output rates with low energy input requirements [4]. During fermentation, different anaerobic groups such as Enterobacter, Clostridium, Bacillus and Thermotoga convert several organic and complex carbohydrate rich-substrates (sugary wastewater, cellulose, municipal solid waste and corn pulp) to $\mathrm{H}_{2}, \mathrm{CO}_{2}$, carboxylic acids and organic solvents [5].

Different methods have been used to measure the hydrogen produced. In general, the choice of appropriate technique depends on the size of the anaerobic reactor and the sensitivity and capacity of the gas-measuring apparatus. The techniques proposed generally range from the low-cost intermittent pressure release method (Owen method, [6]) where yields are usually reduced due to high partial pressures of hydrogen, to the more expensive continuous gas release method using a bubble measurement device (respirometric method, [6]). Note that calibrated pressure manometers can be also used to measure the production of specific gas in anaerobic lab-scale reactors. However, the method requires careful calibration of gas volume versus pressure, and accurate measurement of the production of specific gases is made difficult by the fact that calibration is related to gas composition and solubility, temperature, headspace volume, and ratio of liquid to gas volume. Other techniques can also 
be used, such as wet-test or wet-tip meters, lubricated syringes, and manometer-assisted syringes, but these methods are unfortunately labour-intensive, time-consuming and/or subject to numerous sources of error.

Anaerobic respirometers could help overcome these deficiencies and save considerable test time. These instruments were purpose-designed to automatically give precise instantaneous measurements of gas production on a continuous basis in increments as small as $0.1 \mathrm{~mL}$, and record the data by counters or computers. The technique is not just accurate but also advantageous as it does not allow significant pressure buildup.

Previous biohydrogen production studies conducted in two types of batch tests (Owen and respirometer) showed that under otherwise identical conditions, the respirometric method resulted in the production of $43 \%$ more hydrogen gas from glucose than the Owen method [6]. In other studies, the composition and total mass flow rate of outlet biogas mixture $\left(\mathrm{O}_{2}, \mathrm{H}_{2}\right.$ and $\mathrm{CO}_{2}$ ) produced by fermentation were measured on-line with a mass flow-meter associated with a mass spectrometer $[7,8]$. These instruments enabled to follow the instantaneous kinetics of gases released or consumed by the culture. The use of mass spectrometry was described as advantageous as it is a sensitive, high-resolution separation technique with wide applicability. Specific electrodes such as Pt electrode or Clark-type electrode used to determine $\mathrm{H}_{2}$ production rate in the gas phase as well as in aqueous solution for different cultures were considered sensitive instruments but still only efficient at low hydrogen concentrations $[9,10]$.

A multi-channel analyzer called the Automatic Methane Potential Test System (AMPTS) has been used as a laboratory instrument to measure the biohydrogen produced from cheese whey by dark fermentation [11]. This instrument was developed for automatic real-time measurement of biogas production during anaerobic digestion from any organic biomass [12]. It gives reproducible results due to the relatively high number of parallel 
experiments and the possibility to directly compare different process configurations. Recently, Donval \& Guyader [13] developed a specific analytical device based on the headspace method for quantifying $\mathrm{H}_{2}$ and $\mathrm{CH}_{4}$ in seawater at trace level. The aim was to have a compact, portable and automated system composed of independent and heavy instruments such as valves (selection, sampling, open/close), small oven, controlled micropump in a time program via an electronic interface. No gas chromatograph was used to keep analytical system weight and dimensions to a minimum. Jones et al. [14] also proposed an original technique based on measuring percentages of gas (methane, carbon dioxide, hydrogen) removed from the headspace with specific sensors placed in a gas loop connected to the fermenter. Among all these instruments, gas chromatography (GC) employing a thermal conductivity detector (TCD) remains the classic widely-used technique for measuring widely varying hydrogen concentrations [15]. This analytical technique is characterized by a good resolution and sensitivity, a short analysis time, a high separation power and an easy recording data. The main problem related to this instrument remains its high cost compared to other simple devices.

The aim of this study was to propose a simple and indirect technique to determine partial pressure of hydrogen in serum bottles during anaerobic fermentation. Mesophilic and hyperthermophilic hydrogenogenic microorganisms were tested, and the limits of the technique were discussed.

\section{Material and Methods}

Strains and growth media

Four strains were used in this study: Thermotoga maritima MSB8 (DSMZ 3109) (TM), Thermococcus kodakarensis KOD1 (JCM 12380) (TK), Enterobacter cloacae (ATCC 35929) (EC), and Caldicellulosiruptor saccharolyticus (CS) belonging to the orders 
Thermotogales, Thermococcales, Enterobacteriales and Thermoanaerobacteriales, respectively. Optimal growth temperature for each strain was $80{ }^{\circ} \mathrm{C}$ for $\mathrm{TM}$ and $\mathrm{TK}, 70{ }^{\circ} \mathrm{C}$ for $\mathrm{CS}$ and $35^{\circ} \mathrm{C}$ for EC.

Three strains (TM, TK and CS) were cultured using a common basal medium (BM) containing (per liter) $\mathrm{NH}_{4} \mathrm{Cl} 0.5 \mathrm{~g}, \mathrm{KH}_{2} \mathrm{PO}_{4} 0.3 \mathrm{~g}, \mathrm{NaCl} 20 \mathrm{~g}$ and $\mathrm{Na}_{2} \mathrm{HPO}_{4} 0.3 \mathrm{~g}$ to which Balch's trace-mineral-element solution $(10 \mathrm{~mL})$ was added [16]. The medium was $\mathrm{pH}$ adjusted to 7.0 with $1 \mathrm{~mol} \mathrm{~L}-1 \mathrm{NaOH}$, then autoclaved at $120^{\circ} \mathrm{C}$ for $20 \mathrm{~min}$ and stored at room temperature. The Enterobacter cloacae (EC) strain was cultivated in a BM containing (per liter) $\mathrm{NH}_{4} \mathrm{Cl} 1 \mathrm{~g}, \mathrm{KH}_{2} \mathrm{PO}_{4} 0.3 \mathrm{~g}, \mathrm{~K}_{2} \mathrm{HPO}_{4} 0.3 \mathrm{~g}, \mathrm{CaCl}_{2} 0.2 \mathrm{~g}, \mathrm{NaCl} 20 \mathrm{~g}$ and $\mathrm{KCl} 1 \mathrm{~g}$ to which Balch's trace-mineral-element solution $(10 \mathrm{~mL})$ was added.

A second BM (BM1) was used with the same ingredient composition as BM but with the concentrations of $\mathrm{KH}_{2} \mathrm{PO}_{4}$ and $\mathrm{Na}_{2} \mathrm{HPO}_{4}$ increased to $0.6 \mathrm{~g} / \mathrm{L}$ and $5 \mathrm{~g} / \mathrm{L}$, respectively.

Thermotoga Maritima. Before inoculation, the BM was supplemented with glucose (15 mM), yeast extract $1 \mathrm{~g} / \mathrm{L}, \mathrm{CaCl}_{2} 0.1 \mathrm{~g} / \mathrm{L}, \mathrm{MgCl}_{2} 0.3 \mathrm{~g} / \mathrm{L}$, cysteine- $\mathrm{HCl} 0.3 \mathrm{~g} / \mathrm{L}$ and $\mathrm{Na}_{2} \mathrm{~S}$ 0.4g/L. T. maritima cultures performed in serum bottles were incubated at $80^{\circ} \mathrm{C}$.

Thermococcus kodakarensis. After sterilization, the BM was supplemented with glucose $(15 \mathrm{mM})$ and elemental sulfur $(5 \mathrm{~g} / \mathrm{L})$. TK was cultivated under strictly anaerobic conditions at $80^{\circ} \mathrm{C}[17]$.

Caldicellulosiruptor saccharolyticus. Before inoculation, the BM was supplemented with yeast extract $1 \mathrm{~g} / \mathrm{L}, \mathrm{CaCl}_{2} 2 \mathrm{H}_{2} \mathrm{O} 0.10 \mathrm{~g} / \mathrm{L}, \mathrm{MgCl}_{2} 6 \mathrm{H}_{2} \mathrm{O} 0.2 \mathrm{~g} / \mathrm{L}$, cysteine- $\mathrm{HCl} 0.5 \mathrm{~g} / \mathrm{L}$, cellobiose $1 \mathrm{M}(0.5 \mathrm{~mL})$ and $\mathrm{Na}_{2} \mathrm{~S} 2 \%(0.5 \mathrm{~mL})$ and the $\mathrm{CS}$ culture was incubated at $70^{\circ} \mathrm{C}$.

Enterobacter cloacae. After sterilization, the BM was supplemented with $\mathrm{MgCl}_{2}$, $6 \mathrm{H}_{2} \mathrm{O} 0.2 \mathrm{~g} / \mathrm{L}$, yeast extract $2 \mathrm{~g} / \mathrm{L}$, peptone $2 \mathrm{~g} / \mathrm{L}$ and maltose $(0.5 \mathrm{M})$. EC cultures performed in serum bottles were incubated at $35^{\circ} \mathrm{C}$. 


\section{Preparation of media and stock solutions}

The medium was boiled then cooled down to room temperature under a stream of $\mathrm{O}_{2-}$ free $\mathrm{N}_{2}$, then distributed into $116-\mathrm{mL}$ serum bottles ( $25 \mathrm{~mL}$ of medium). After sealing the serum bottles, the gaseous phase was flushed with a stream of $\mathrm{O}_{2}$-free $\mathrm{N}_{2}$ for $30 \mathrm{~min}$. The medium was then autoclaved at $120^{\circ} \mathrm{C}$ for $20 \mathrm{~min}$ and stored at room temperature. All stock solutions were prepared under anoxic conditions as described by Miller \& Wolin [18], and stored under $\mathrm{O}_{2}$-free $\mathrm{N}_{2}$. Glucose $(2 \mathrm{M})$, fructose $(2 \mathrm{M})$, maltose $(1 \mathrm{M})$ and cellobiose solutions, yeast extract and peptone were sterilized by filtration. $\mathrm{Na}_{2} \mathrm{~S}(2 \%)$, cysteine- $\mathrm{HCl}(5 \%), \mathrm{MgCl}_{2}$ (3\%) and $\mathrm{CaCl}_{2}(2 \%)$ solutions were sterilized by autoclaving $\left(120^{\circ} \mathrm{C}\right.$ for $\left.20 \mathrm{~min}\right)$.

\section{Experimental systems and operating conditions}

All strains were grown in $116 \mathrm{~mL}$ serum bottles with $30 \mathrm{~mL}$ of culture medium after inoculation. Before culture, the serum bottle was sealed with rubber stoppers, and anoxia was obtained by flushing the bottle headspaces with an $\mathrm{O}_{2}$-free $\mathrm{N}_{2}$ gas stream for 20 minutes. All the bottles were placed in a temperature-controlled oven $\left( \pm 0.1^{\circ} \mathrm{C}\right)$.

The measurements of total pressure and $\mathrm{H}_{2}$ concentration in the headspace were made after transferring the bottles to a temperature-controlled $\left( \pm 0.1^{\circ} \mathrm{C}\right)$ heating water bath at the optimal temperature for each strain (Fig. 1).

\section{Analytical methods}

During fermentation, hydrogen contents were periodically measured by withdrawing $250 \mu \mathrm{L}$ gas samples from the serum bottle headspace in gas-tight syringes and injecting the samples into a GC-TCD system (Perichrom, France) equipped with a concentric CTR1 column (Alltech, USA). Operating temperatures of the detector, injector and oven were $100^{\circ} \mathrm{C}, 100^{\circ} \mathrm{C}$ and $40^{\circ} \mathrm{C}$, respectively. Argon was used as carrier gas at a flow rate of 20 
mL.min ${ }^{-1}$. This system was connected to a computer running WINILAB III software (Perichrom, France). A GC-TCD calibration curve was generated by running various dilutions of the $\mathrm{H}_{2}$ and $\mathrm{CO}_{2}$ and then plotting response times against concentration.

Total pressure in the headspace of the serum bottles was measured using a manometer (Wika, France) with a fine needle robust enough to pass through the rubber stopper with any deformation. The manometer gave full-scale readings of 2 bars at an accuracy of \pm 10 mbars.

For some experiments, to determine $\mathrm{pH}$, the entire culture medium contained in the serum bottles was withdrawn at different times. $\mathrm{pH}$ was also determined from the culture medium at the end of all experiments.

At the end of fermentation, concentrations of the main soluble metabolite products (acetate, lactate, butyrate, ethanol, formate, etc.) and residual glucose were analyzed. Liquid samples harvested from the serum bottles were centrifuged at $14000 \mathrm{~g}$ for $5 \mathrm{~min}$, and the supernatants were filtered through a $0.45-\mu \mathrm{m}$ cellulose acetate minisart@ syringe filters (Sartorius Stedim). They were analyzed by HPLC (Agilent 1200 series, USA) on a system equipped with a quaternary pump coupled to a refractometer index detector and $300 \times 7.8 \mathrm{~mm}$ Aminex HPX-87 H ion-exchange columns (Bio-Rad). The HPLC system was connected to a computer running WINILAB III software (Perichrom, France). Sulfuric acid $5 \mathrm{mM}$ (in milliQ water) was used as mobile phase at a flow rate of $0.5 \mathrm{~mL} / \mathrm{min}$. All analyses were performed in duplicate.

\section{Theory}

Total pressure $\left(\mathrm{P}_{\mathrm{t}}\right)$ in the headspace of the serum bottle is defined as follows:

$$
\mathrm{P}_{\mathrm{t}}=\mathrm{P}_{\mathrm{vs}\left(\mathrm{H}_{2} \mathrm{O}\right)}(\mathrm{T})+\mathrm{P}_{\mathrm{exp}}(\mathrm{T})+\mathrm{P}_{\text {prod }}
$$


where $\mathrm{P}_{\mathrm{vs}\left(\mathrm{H}_{2} \mathrm{O}\right)}(\mathrm{T})$ is the saturation pressure of water and $\mathrm{P}_{\text {exp }}(\mathrm{T})$ is the pressure expansion of gases, both depending on temperature $(\mathrm{T})$, and $\mathrm{P}_{\text {prod }}$ is the sum of the partial pressures of the volatile compounds produced during the fermentation.

$\mathrm{P}_{\mathrm{vs}\left(\mathrm{H}_{2} \mathrm{O}\right)}(\mathrm{T})$ was calculated using Antoine's equation [19]

$$
\mathrm{P}_{\mathrm{vs}\left(\mathrm{H}_{2} \mathrm{O}\right)}(\mathrm{T})=\exp ^{\left[\mathrm{A}-\left(\frac{\mathrm{B}}{\mathrm{C}+\mathrm{T}}\right)\right]}
$$

with $\mathrm{A}=16.39, \mathrm{~B}=3885.7$ and $\mathrm{C}=230.17 . \mathrm{T}$ is in ${ }^{\circ} \mathrm{C}$ and $\mathrm{P}_{\mathrm{vs}\left(\mathrm{H}_{2} \mathrm{O}\right)}(\mathrm{T})$ is in $\mathrm{Pa}$.

$\mathrm{P}_{\exp }(\mathrm{T})$ was determined as follows:

$$
\mathrm{P}_{\exp }(\mathrm{T})=\mathrm{P}\left(\mathrm{T}_{0}\right) \frac{\mathrm{T}}{\mathrm{T}_{0}}
$$

with $\mathrm{P}_{\exp }(\mathrm{T})$ in $\mathrm{Pa}, \mathrm{T}_{0}=293^{\circ} \mathrm{K}$ and $\mathrm{P}\left(\mathrm{T}_{0}\right)=101325 \mathrm{~Pa}$.

$\mathrm{P}_{\text {prod }}=\sum_{\alpha} \mathrm{P}_{\mathrm{g} \alpha}$

with $\alpha=\mathrm{H}_{2}, \mathrm{CO}_{2}$ and volatile-compound end-products.

The thermodynamic equilibrium of the dissolved compounds $\alpha$ is described by Henry's law:

$\left[\mathrm{C}_{\alpha}\right]=\mathrm{K}_{\mathrm{h}}(\mathrm{T}) \mathrm{P}_{\mathrm{g} \propto}$

Here, $\left[\mathrm{C}_{\alpha}\right]$ is concentration of the $\alpha$ compound in the aqueous phase, $\mathrm{P}_{\mathrm{g} \alpha}$ is partial pressure of the $\alpha$ compound in the gas phase under equilibrium conditions, and $K_{h}(T)$ is Henry's constant $(\mathrm{mol} / \mathrm{L} / \mathrm{Pa})$ for the $\alpha$ compound at temperature $\mathrm{T}\left({ }^{\circ} \mathrm{K}\right)[20]$.

$$
\mathrm{K}_{\mathrm{h}}(\mathrm{T})=\mathrm{K}_{\mathrm{h}}^{\theta} \exp \left(\frac{-\Delta_{\text {soln }} \mathrm{H}}{\mathrm{R}}\left(\frac{1}{\mathrm{~T}}-\frac{1}{\mathrm{~T}^{\theta}}\right)\right)
$$

$\mathrm{K}_{\mathrm{h}}^{\theta}$ refers to standard conditions $\left(\mathrm{T}^{\theta}=298.15^{\circ} \mathrm{K}\right) . \Delta_{\text {soln }} \mathrm{H}$ is the enthalpy of solution ( $\mathrm{Pa}$ $\mathrm{L} / \mathrm{mol})$, and $\mathrm{R}$ is the ideal gas constant $\left(\mathrm{Pa} \mathrm{L} / \mathrm{mol}^{\circ} \mathrm{K}\right)$.

$\mathrm{CO}_{2}$ does dissolve in water. The $\mathrm{CO}_{2}$ in the aqueous phase is only in equilibrium with the hydrogen carbonate $\mathrm{HCO}_{3}^{-}$as the dissociation of $\mathrm{HCO}_{3}^{-}$into $\mathrm{CO}_{3}^{2-}$ can be considered 
negligible at $\mathrm{pH} \leq 7$. The conversion reaction between $\mathrm{CO}_{2}$ and $\mathrm{HCO}_{3}^{-}$and the corresponding dissociation constant are as follows:

$$
\begin{array}{r}
{\left[\mathrm{CO}_{2}\right]+\left[\mathrm{H}_{2} \mathrm{O}\right] \rightleftarrows\left[\mathrm{H}^{+}\right]+\left[\mathrm{HCO}_{3}^{-}\right]} \\
\mathrm{K}_{1}=\frac{\left[\mathrm{H}^{+}\right]\left[\mathrm{HCO}_{3}^{-}\right]}{\left[\mathrm{CO}_{2}\right]}
\end{array}
$$

with $\left[\mathrm{H}^{+}\right]=10^{-\mathrm{pH}}$

Total dissolved $\mathrm{CO}_{2}\left(\left[\mathrm{C}_{\mathrm{T}}\right]\right)$ is the sum of the concentrations of $\mathrm{CO}_{2}\left(\left[\mathrm{C}_{\mathrm{CO}_{2}}\right]\right)$ and $\mathrm{HCO}_{3}^{-}$ $\left(\left[\mathrm{HCO}_{3}^{-}\right]\right)$in the aqueous phase:

$\left[\mathrm{C}_{\mathrm{T}}\right]=\left[\mathrm{C}_{\mathrm{CO}_{2}}\right]+\left[\mathrm{HCO}_{3}^{-}\right]$

Using equations $5,6,8$ and $9,\left[\mathrm{C}_{\mathrm{T}}\right]$ is:

$$
\left[\mathrm{C}_{\mathrm{T}}\right]=\mathrm{P}_{\mathrm{gCO}_{2}} \mathrm{~K}_{\mathrm{h}}(\mathrm{T})\left(1+\frac{\mathrm{K}_{1}}{10^{-\mathrm{pH}}}\right)
$$

$\mathrm{K}_{\mathrm{h}}(\mathrm{T})$ was obtained from Sander and $\mathrm{K}_{1}$ was obtained from Amend and Shock $[20,21]$. For a temperature of $80^{\circ} \mathrm{C}, \mathrm{K}_{\mathrm{h}}$ and $\mathrm{K}_{1}$ were $0.95810^{-7} \mathrm{~mol} / \mathrm{L} / \mathrm{Pa}$ and $0.49310^{-6}$ mol/L, respectively. For a temperature of $35^{\circ} \mathrm{C}, \mathrm{K}_{\mathrm{h}}$ and $\mathrm{K}_{1}$ were $2.58410^{-7} \mathrm{~mol} / \mathrm{L} / \mathrm{Pa}$ and $0.46310^{-6} \mathrm{~mol} / \mathrm{L}$, respectively. 
Among the wide range of byproducts from microbial metabolism, the two metabolic pathways producing hydrogen from carbohydrates are essentially the "acetate" and "butyrate" pathways well known in many species of Thermotogae, Thermococcaceae, Thermoanaerobacteraceae (eq. 12) and Enterobacteriaceae (eq. 13). The production of acetate gives a theoretical stoichiometric yield of 2 moles of $\mathrm{H}_{2}$ per mole of $\mathrm{CO}_{2}$, while in the butyrate pathway; molar hydrogen yield is lower, at 1 mole of $\mathrm{H}_{2}$ per mole of $\mathrm{CO}_{2}$.

$$
\begin{aligned}
& \mathrm{C}_{6} \mathrm{H}_{12} \mathrm{O}_{6}+2 \mathrm{H}_{2} \mathrm{O} \rightarrow 2 \mathrm{C}_{2} \mathrm{H}_{4} \mathrm{O}_{2}+2 \mathrm{CO}_{2}+4 \mathrm{H}_{2} \\
& \mathrm{C}_{6} \mathrm{H}_{12} \mathrm{O}_{6} \rightarrow 2 \mathrm{C}_{4} \mathrm{H}_{8} \mathrm{O}_{2}+2 \mathrm{CO}_{2}+2 \mathrm{H}_{2}
\end{aligned}
$$

\section{Results and Discussion}

\section{Determination of the total pressure for abiotic experiments}

First we used empty 116-mL serum-bottles to determine whether total pressure measured in the bottles remained constant after several punctures with the manometer needle. Overpressure (800 mbar) in the closed bottle was obtained by introducing a constant $\mathrm{N}_{2}$ flow rate. After 6 successive manometer-needle punctures in the bottle-cap septum, total pressure was kept quasi-constant at $790 \pm 10$ mbar. Six additional $250 \mu \mathrm{L}$ samples of gas were withdrawn from the bottle using a gas syringe to simulate the successive samplings required for gas chromatography measurement of percentage $\mathrm{H}_{2}$ in the headspace of the bottles. The decrease in total pressure due to the 6 punctures was $1.5 \%$, i.e. equivalent to a pressure of less than 12 mbar. These results show that (i) gas leakage was very low, (ii) dead volume of the manometer was negligible, and (iii) successive samples made with the gas syringe lead to very little pressure drop in the serum-bottle headspace.

Experiments were performed to measure total pressure $\left(\mathrm{P}_{\mathrm{t}}\right)$ in the headspace of serum bottles at three temperatures $\left(35,70\right.$ and $\left.80^{\circ} \mathrm{C}\right)$ corresponding to the optimum culture temperatures of E. cloacae, C. saccharolyticus, and T. maritima and T. kodakarensis, 
respectively. All serum bottles contained $30 \mathrm{~mL}$ of pure water. Bottle transfer from oven to water bath was quick, and consequently the equilibrium of total pressure in the headspace was reached in less than one minute. In this case, $\mathrm{P}_{t}$ is the sum of $\mathrm{P}_{\mathrm{vs}}\left(\mathrm{H}_{2} \mathrm{O}\right)$ deduced from equation 2 and $\mathrm{P}_{\mathrm{exp}}\left(\right.$ eq. $\left.1, \mathrm{P}_{\text {prod }}=0\right)$ deduced from equation 3 (Table 1). The sum of $\mathrm{P}_{\mathrm{vs}\left(\mathrm{H}_{2} \mathrm{O}\right)}$ and $\mathrm{P}_{\exp }$ was compared to $\mathrm{P}_{\mathrm{t}}$, measured by the manometer. For these three temperatures, $\mathrm{P}_{\mathrm{t}}$ measured by the manometer and $\mathrm{P}_{\mathrm{t}}$ determined from theoretical calculation were near-identical (Table 1). The effect of the volatile compounds released at $80{ }^{\circ} \mathrm{C}$ by the culture medium in the headspace of the serum bottle was evaluated. No overpressure was measured showing that the volatility of the culture medium compounds was negligible (data not shown).

\section{Determination of total pressure and $\mathrm{H}_{2}$ partial pressure during microbial growth}

Experiments were performed with two hyperthermophilic (T. maritima and $T$. kodakarensis) and one mesophilic (E. cloacae) microorganisms by measuring $\mathrm{P}_{\mathrm{t}}$ and $\mathrm{P}_{\mathrm{gH}_{2}}$ by gas manometer and gas chromatography, respectively, 6 times for each bottle. This experimental protocol was shown to not reduce the total pressure in the headspace (see above). Whatever the microorganism used in these experiments, the pressure $\left(\mathrm{P}_{t}\right)$ measured in the headspace is the contribution of physical $\left(\mathrm{P}_{\mathrm{vs}\left(\mathrm{H}_{2} \mathrm{O}\right)}+\mathrm{P}_{\mathrm{exp}}\right)($ eqs. 2 and 3) and biological ( $\mathrm{P}_{\text {prod}}$ ) phenomena (eq. 4). The term $\mathrm{P}_{\mathrm{vs}\left(\mathrm{H}_{2} \mathrm{O}\right)}+\mathrm{P}_{\exp }$ depends on the temperature and is constant with time (Table 1). $\mathrm{P}_{\text {prod }}$ is the sum of the partial pressures of $\mathrm{H}_{2}, \mathrm{CO}_{2}$ and volatilecompound end-products. Among the wide range of byproducts, various metabolic pathways producing hydrogen from carbohydrates are essentially the "acetate" pathway (eq. 12) or the "butyrate" pathway (eq. 13) well known in many species of Thermotogae and Enterobacteriacae, respectively. Others end-products such as lactate, formate and ethanol are also observed but at lower concentrations. The $K_{h}(T)$ values [20] for each end-product $(\alpha=$ acetate, butyrate, lactate, etc.) were determined using equation $6 . \mathrm{P}_{\mathrm{g} \propto}$ was calculated from 
equation 5, considering a concentration of the $\alpha$ compound in the aqueous phase $\left[\mathrm{C}_{\alpha}\right]$ of 40 $\mathrm{mmol} / \mathrm{L}[16]$. All of these compounds had a $\mathrm{P}_{\mathrm{g} \propto}$ of less than 1 mbar for temperatures between 35 et $80^{\circ} \mathrm{C}$, showing that their partial pressures are negligible compared to the partial pressures of $\mathrm{H}_{2}$ and $\mathrm{CO}_{2}$. Subsequently, for this study we consider that $\mathrm{P}_{\text {prod }}$ is only the sum of $\mathrm{P}_{\mathrm{gH}_{2}}$ and $\mathrm{P}_{\mathrm{gCO}_{2}}$. $\mathrm{P}_{\text {prod }}$ was then deduced from the manometer measurement of $\mathrm{P}_{\mathrm{t}}$ by subtracting $\mathrm{P}_{\mathrm{vs}\left(\mathrm{H}_{2} \mathrm{O}\right)}(\mathrm{T})+\mathrm{P}_{\exp }(\mathrm{T})$ (eq. 1, Table 1).

Figures 2, 3 and 4 represent the relation between the partial pressure of $\mathrm{H}_{2}$ measured by gas chromatography $\left(\mathrm{P}_{\mathrm{gH}_{2}}\right)$ and $\mathrm{P}_{\text {prod }}$ deduced from the total pressure measured by the manometer gauge for the three microorganisms T. maritima, T. kodakarensis and E. cloacae. For all strains, a linear relation between $\mathrm{P}_{\mathrm{gH}_{2}}$ and $\mathrm{P}_{\text {prod }}$ was obtained with a relatively good correlation coefficient $(0.975<\mathrm{R}<0.995)$. The slope of regression line $(\beta)$ was almost the same for the two hyperthermophilic strains T. maritima (0.623, Fig. 2) and T. kodakarensis (0.653, Fig. 3) but lower for the mesophilic bacteria E. cloacae (0.46, Fig. 4). Slope of regression line $(\beta)$ is the ratio between $\mathrm{P}_{\mathrm{gH}_{2}}$ and $\mathrm{P}_{\text {prod. }}$

$$
\begin{gathered}
\frac{\mathrm{P}_{\mathrm{gH}_{2}}}{\mathrm{P}_{\text {prod }}}=\left(\frac{\mathrm{P}_{\mathrm{gH}_{2}}}{\mathrm{P}_{\mathrm{gH}_{2}}+\mathrm{P}_{\mathrm{gCO}_{2}}}\right)=\beta \\
\frac{\mathrm{P}_{\mathrm{gH}_{2}}}{\mathrm{P}_{\mathrm{gCO}_{2}}}=\frac{\beta}{1-\beta}
\end{gathered}
$$

with $\mathrm{P}_{\text {prod }}=\mathrm{P}_{\mathrm{gH}_{2}}+\mathrm{P}_{\mathrm{gCO}_{2}}$

Using equation 15 with the $\beta$ values determined for each strain (Fig. 2, 3 and 4), $\mathrm{P}_{\mathrm{gH}_{2}} / \mathrm{P}_{\mathrm{gCO}_{2}}$ ratios were 1.7, 1.9 and 0.9 for T. maritima, T. kodakarensis and E. cloacae, respectively. The main end-products measured at the end of experiments for T. maritima and T. kodakarensis and E. cloacae were acetate and butyrate (data not shown), respectively, as reported by different authors $[16,22]$. The $\mathrm{P}_{\mathrm{gH}_{2}} / \mathrm{P}_{\mathrm{gCO}_{2}}$ ratios were comparable to the stoichiometric 
parameters obtained from equations 12 and 13, essentially associated with the "acetate" $\left(\mathrm{H}_{2} / \mathrm{CO}_{2}=2\right)$ and "butyrate" $\left(\mathrm{H}_{2} / \mathrm{CO}_{2}=1\right)$ pathways. Five experiments were performed using $C$. saccharolyticus, an extreme thermophilic strain, in which $\mathrm{P}_{\mathrm{gH}_{2}}$ and $\mathrm{P}_{\text {prod }}$ were measured by gas chromatography and manometer gauge, respectively, only at the end of experiment when $\mathrm{H}_{2}$ production was maximum. $\mathrm{P}_{\mathrm{gH}_{2}}$ was $116.5 \pm 15$ mbar and $\mathrm{P}_{\text {prod }}$ was $180 \pm 10$ mbar. $C$. saccharolyticus uses the "acetate" pathway (acetate was main end-product; data not shown). In this case, when the stoichiometric parameter (eq. $\left.12\left(\mathrm{H}_{2} / \mathrm{CO}_{2}=2\right)\right)$ was applied, $\mathrm{P}_{\mathrm{gH}_{2}}$ was 120 mbar, i.e. very close to that measured by gas chromatography (116.5 \pm 15 mbar). Considering the similarities between these techniques, the correct use of a manometer gauge could be considered as a simple instrument, efficient enough to measure the partial pressure of hydrogen produced during anaerobic fermentation, with maximum accuracy at minimal cost, in terms of both time and cost.

Partial pressure of $\mathrm{H}_{2}\left(\mathrm{P}_{\mathrm{gH}_{2}}\right)$ is an important factor for continuous $\mathrm{H}_{2}$ synthesis. Boileau et al [16] showed that the cellular-production rate and the glucose-consumption rate of T. maritima were not afected when $\mathrm{P}_{\mathrm{gH}_{2}}$ was maintained in a range of 7-178 mbar. This result is consistent with some authors' conclusion that a $\mathrm{P}_{\mathrm{gH}_{2}}$ lower than 200 mbar was required for an optimal growth [23-25]. Moreover, when $\mathrm{P}_{\mathrm{gH}_{2}}$ increases, metabolic pathways shift to production of more reduced substrates such as lactate, ethanol, acetone, etc.... Van Niel et al. [24] reported that for $\mathrm{P}_{\mathrm{gH}_{2}}$ higher than 200 mbar, lactate becomes the dominant fermentation product during $C$. saccharolyticus growth. To our knowledge, no information on the effect of $\mathrm{P}_{\mathrm{gH}_{2}}$ on T. kodakarensis and E. cloacae growth cultured in serum bottles is available.

Effect of pH on the $\mathrm{P}_{\mathrm{gH}_{2}} / \mathrm{P}_{\mathrm{gCO}_{2}}$ ratio during $\mathrm{H}_{2}$ production 
Analysis found a linear relationship between $\mathrm{P}_{\mathrm{gH}_{2}}$ and $\mathrm{P}_{\mathrm{gH}_{2}}+\mathrm{P}_{\mathrm{gCO}_{2}}$ for T. maritima, T. kodakarensis and E. cloacae. Moreover, the $\mathrm{P}_{\mathrm{gH}_{2}} / \mathrm{P}_{\mathrm{gCO}_{2}}$ ratios obtained from the experiments are close to the stoichiometric parameters of the most plausible metabolic pathways of each strain (eqs. 12 and 13). Initial $\mathrm{pH}$ was $7.0 \pm 0.1$ for all three microorganisms. Final $\mathrm{pH}$ was $5 \pm 0.2$ for $T$. maritima and T. kodakarensis and $4.4 \pm 0.2$ for E. cloacae. Therefore, as the dissociation of $\left[\mathrm{HCO}_{3}^{-}\right]$into $\left[\mathrm{CO}_{3}^{2-}\right]$ can be considered negligible at $\mathrm{pH} \leq 7$, total dissolved $\mathrm{CO}_{2}\left(\left[\mathrm{C}_{\mathrm{T}}\right]\right.$ ) (eq. 10) is only the sum of the concentration of $\mathrm{CO}_{2}$ $\left(\left[\mathrm{C}_{\mathrm{CO}_{2}}\right]\right)$ and the concentration of $\mathrm{HCO}_{3}^{-}\left(\left[\mathrm{HCO}_{3}^{-}\right]\right)$. At the end of the experiments, $\mathrm{pH}$ was low $(\leq 5)$ for all three microorganisms. Consequently, dissolved $\mathrm{CO}_{2}\left(\left[\mathrm{C}_{\mathrm{T}}\right]\right)$ in the aqueous phase is low, and most of the $\mathrm{CO}_{2}$ is present in the headspace of the bottles.

$\mathrm{CO}_{2}\left(\left[\mathrm{C}_{\mathrm{CO}_{2}}\right]\right)$ and $\mathrm{HCO}_{3}^{-}\left(\left[\mathrm{HCO}_{3}^{-}\right]\right)$concentrations in the aqueous phase were calculated using equations 5, 6, 10 and 11, taking into account a final $\mathrm{P}_{\mathrm{gCO}_{2}}$ of 100 mbar for T. maritima and T. kodakarensis and 130 mbar for E. cloacae (Fig. 2, 3 and 4). For the two hyperthermophilic microorganisms, dissolved $\mathrm{CO}_{2}\left(\left[\mathrm{C}_{\mathrm{T}}\right]\right)$ in the aqueous phase represented $10 \%$ of total $\mathrm{CO}_{2}$ produced at the end of the experiment. These $10 \%$ are distributed as follows: $95 \%$ of $\mathrm{C}_{\mathrm{CO}_{2}}$ and $5 \%$ of $\mathrm{HCO}_{3}^{-}$(eq. 10). For E. cloacae, $24 \%$ of total $\mathrm{CO}_{2}$ was dissolved in the aqueous phase $\left(\mathrm{C}_{\mathrm{CO}_{2}}: 95.4 \%\right.$ and $\left.\mathrm{HCO}_{3}^{-}: 4.6 \%\right)$ at the end of experiment. Then, taking into account these values of total dissolved $\mathrm{CO}_{2}\left(\left[\mathrm{C}_{\mathrm{T}}\right]\right)$ in the aqueous phase, the corresponding $\mathrm{P}_{\mathrm{gH}_{2}} / \mathrm{P}_{\mathrm{gCO}_{2}}$ ratios (calculated from equations 5, 6, 8, 10 and 11) were 2.2 for $T$. maritima and T. kodakarensis and 1.24 for E. cloacae. These values are comparable to those obtained experimentally (1.8 and 1.17). The effect of the medium culture acidification on $\mathrm{P}_{\mathrm{gH}_{2}} / \mathrm{P}_{\mathrm{gCO}_{2}}$ ratio was also confirmed for $C$. saccharolyticus, for which final $\mathrm{pH}$ was 4 and the corresponding $\mathrm{P}_{\mathrm{gH}_{2}} / \mathrm{P}_{\mathrm{gCO}_{2}}$ ratio was 1.83 , which is close to the theoretical stoichiometric yield of 2 moles of $\mathrm{H}_{2}$ per mole of $\mathrm{CO}_{2}$ (eq. 11). 
To illustrate the influence of $\mathrm{pH}$, experiments were performed using BM1 for $T$. maritima growth. The increase of $\mathrm{KH}_{2} \mathrm{PO}_{4}$ and $\mathrm{Na}_{2} \mathrm{HPO}_{4}$ concentrations from 0.3 to $0.6 \mathrm{~g} / \mathrm{L}$ and 0.3 to $5 \mathrm{~g} / \mathrm{L}$ was expected to bring better $\mathrm{pH}$ control at around 7 . Figure 5 charts the variation in partial pressures of $\mathrm{H}_{2}$ and $\mathrm{CO}_{2}$ with in $\mathrm{pH}$ versus time during the growth of $T$. maritima for BM1 and BM, respectively. With BM1, pH held quasi-constant during 40 hours (initial $\mathrm{pH}=7 \pm 0.1$ and final $\mathrm{pH}=6.9 \pm 0.1$ ), whereas with $\mathrm{BM}$ it dropped from $7 \pm 0.1$ to $5.5 \pm 0.1$. In both cases, the increase of $\mathrm{H}_{2}$ partial pressure was comparable at hour 40 of the experiment. Peak $\mathrm{P}_{\mathrm{gH}_{2}}$ was 110 mbar (310 mL H$/ 2$ medium). On 48 hours of cultivation of T. maritima with a similar culture medium, Nguyen et al. [26] obtained a maximum cumulative $\mathrm{H}_{2}$ production of about $180 \mathrm{~mL} \mathrm{H} / \mathrm{L}$ medium in batch experiments $(120-\mathrm{mL}$ serum bottles), and showed an effect of different initial $\mathrm{pH}$ values on bacterial growth and hydrogen production. When initial $\mathrm{pH}$ level decreased from 6.5-7.0 to 5.5, there was a $30 \%$ decrease in cumulative $\mathrm{H}_{2}$ production. Here, the same decrease in $\mathrm{pH}$ did not inhibit $\mathrm{H}_{2}$ production by T. maritima: in contrast with Nguyen et al. [26], $\mathrm{pH}$ decreased slowly over 40 hours, allowing T. maritima to gradually adapt. On 40 hours of the experiment, $\mathrm{P}_{\mathrm{gCO}_{2}}$ (Fig. 5) was slightly lower (about 20\%) using BM1. Due to the better control of $\mathrm{pH}(7 \pm 0.2)$ during $T$. maritima growth, more $\mathrm{CO}_{2}\left(\left[\mathrm{C}_{\mathrm{T}}\right]\right)$ got dissolved in the liquid phase, and thus $\mathrm{P}_{\mathrm{gCO}_{2}}$ in the serum-bottle headspace was lower. The difference between the $\mathrm{P}_{\mathrm{gCO}_{2}}$ obtained from $\mathrm{BM} v s$ BM1 seems to be due to the equilibria $\left(\mathrm{CO}_{2}\right.$ gas $\leftrightarrow \mathrm{CO}_{2}$ aqueous $\leftrightarrow \mathrm{HCO}_{3}^{-}$(eq. 10 and 11)) more than the inhibition of $T$. maritima growth due to the decrease in $\mathrm{pH}$ (fig. 5). In a closed serum-bottle without shaking, hydrogen transfer from liquid phase to headspace is limiting. Here, the volumetric mass transfer coefficient (Kla) of hydrogen is several orders of magnitude less than that obtained for a reactor continuously flushed with nitrogen [25,27]. The concentration of dissolved hydrogen will therefore increase rapidly, thus inhibiting the 
growth of T. maritima. In this case, the effect of the decrease in $\mathrm{pH}$ from 7 to 5.5 (Fig. 5) on hydrogen production could be low compared to the effect of hydrogen inhibition.

To illustrate this point and better establish the effect of $\mathrm{pH}$ on $\mathrm{P}_{\mathrm{gCO}_{2}}$ and $\mathrm{P}_{\mathrm{gH}_{2}}$, experiments were conducted using $\mathrm{BM}$ and $\mathrm{BM} 1$ for T. maritima growth. $\mathrm{P}_{\mathrm{gCO}_{2}}$ and $\mathrm{P}_{\mathrm{gH}_{2}}$ were measured by gas chromatography. Figure 6 plots $\mathrm{P}_{\mathrm{gH}_{2}}$ versus $\mathrm{P}_{\mathrm{gCO}_{2}}$ for $\mathrm{BM}$ and $\mathrm{BM} 1$. For both these basal media, we observed a linear regression between $\mathrm{P}_{\mathrm{gH}_{2}}$ and $\mathrm{P}_{\mathrm{gCO}_{2}}$. For $\mathrm{BM}$ and $\mathrm{BM} 1$, the final pHs were consistently within the range of 5-5.5 and 6.6-6.9, respectively. The experimental $\mathrm{P}_{\mathrm{gH}_{2}} / \mathrm{P}_{\mathrm{gCO}_{2}}$ ratios were 2.65 and 2.09 with "controlled" (BM) $\mathrm{pH}$ and "uncontrolled" (BM1) pH, respectively (Fig. 6). The difference between these ratios shows that when $\mathrm{pH}$ remains almost constant (i.e. "controlled"), an amount of $\mathrm{CO}_{2}$ gets solubilized in the liquid phase, whereas when $\mathrm{pH}$ decreases (i.e. "uncontrolled"), a great fraction of $\mathrm{CO}_{2}$ gets transferred to the headspace. Then, the $\mathrm{P}_{\mathrm{gH}_{2}} / \mathrm{P}_{\mathrm{gCO}_{2}}$ ratio (2.65) measured for the "controlled" $\mathrm{pH}$ experiment is therefore logically high compared to the value of the stoichiometric parameter (eq. $12, \mathrm{P}_{\mathrm{gH}_{2}} / \mathrm{P}_{\mathrm{gCO}_{2}}=2$ ). In this case, $58 \%$ of the total $\mathrm{CO}_{2}$ was dissolved in the aqueous phase $\left(\left[\mathrm{C}_{\mathrm{T}}\right]\right)$, as calculated from equations 5,6 and 11 , for $\mathrm{P}_{\mathrm{gCO}_{2}}$ ranging from 10 to 60 mbars (Fig. 6). The corresponding $\mathrm{P}_{\mathrm{gH}_{2}} / \mathrm{P}_{\mathrm{gCO}_{2}}$ value is 3.16 , which is higher than the $\mathrm{P}_{\mathrm{gH}_{2}} / \mathrm{P}_{\mathrm{gCO}_{2}}$ ratio (2.65) obtained experimentally. This higher ratio could be due to over/underestimation of parameters such as the $\mathrm{K}_{\mathrm{h}}(\mathrm{T})$ and $\mathrm{K}_{1}$ coefficients. $T$. maritima is a hyperthermophilic halophile that grows at $20 \mathrm{~g} / \mathrm{L}$ (see Material and Methods). Effects of salt were not taken into account for $\mathrm{K}_{\mathrm{h}}(\mathrm{T})$ and $\mathrm{K}_{1}$ because there is no data available at this salt concentration for a temperature of $80^{\circ} \mathrm{C}$. However, for a temperature of $45^{\circ} \mathrm{C}$, when salinity increased from 2 to $20 \mathrm{~g} / \mathrm{L}, \mathrm{K}_{\mathrm{h}}(\mathrm{T})$ decreased by about $10 \%$ [28] while at the same time $\mathrm{K}_{1}$ increased by $30 \%$ [29]. The decrease of $\mathrm{K}_{\mathrm{h}}(\mathrm{T})$ releases $\mathrm{CO}_{2}$ from the aqueous phase to the headspace, which consequently decreases the value of the $\mathrm{P}_{\mathrm{gH}_{2}} / \mathrm{P}_{\mathrm{gCO}_{2}}$ 
ratio. At the same time, the increases of $K_{1}$ will have the effect of shifting the equilibrium $\left(\mathrm{CO}_{2}\right.$ aqueous $\left.\leftrightarrow \mathrm{HCO}_{3}^{-}\right)$towards $\mathrm{HCO}_{3}^{-}$and thus decrease the $\mathrm{CO}_{2}$ concentration in the aqueous phase. Many authors have studied $\mathrm{CO}_{2}$ transport across the air-sea interface using the stagnant film model theory [30-32], and shown that the exchange mechanism for $\mathrm{CO}_{2}$ gas may indeed vary with the environmental conditions. The rate of $\mathrm{CO}_{2}$ exchange near the air-sea interface is influenced by chemical processes (i.e. hydration/dehydration reactions) [32]. In particular, the rate of $\mathrm{CO}_{2}$ exchange for a solution $\mathrm{pH}$ in the 6.5 region (where $\mathrm{CO}_{2}$ can react with water and hydroxyl ions to a significant extent) was found to be greater than the rate in the $\mathrm{pH}<4$ region (where $\mathrm{CO}_{2}$ effectively acts as an inert gas) [31]. More studies are needed to improve our understanding of these mechanisms and more accurately determine the $\mathrm{K}_{\mathrm{h}}(\mathrm{T})$ and $\mathrm{K}_{1}$ coefficients at high temperature in the presence of salt.

\section{Conclusion}

Here we demonstrated that under certain assumptions, the hydrogen partial pressure of T. maritima, T. kodakarensis and E. cloacae cultures in closed serum bottles can feasibly be determined using a simple manometer. However, the use of this technique requires (i) that the main volatile compounds in the serum-bottle headspace are hydrogen, carbon dioxide and water vapor, (ii) that the metabolic pathway of the hydrogen-producing microorganisms is known, which makes it possible to use the stoichiometric $\mathrm{H}_{2} / \mathrm{CO}_{2}$ yield ratio, and (iii) that $\mathrm{pH}$ decreases during the fermentation, releasing a maximum of dissolved $\mathrm{CO}_{2}$ from the culture medium into the serum-bottle headspace. Further studies are needed to better understand the mechanisms of $\mathrm{H}_{2}$ and $\mathrm{CO}_{2}$ transfer from the liquid to the gaseous phase of the serum bottle, and the effects of salinity and high temperature on Henry's law constant for $\mathrm{CO}_{2}$ and the dissociation constant for $\mathrm{CO}_{2}$ into the bicarbonate ion, respectively. 


\section{Competing interests}

The authors declare that they have no competing interests.

\section{Acknowledgements}

The authors thank the National Institute of Applied Sciences and Technology (INSAT, Tunisia), the Tunisian Ministry of Higher Education and Scientific Research, and the French Institute for Development Research (IRD) through the young associated BiotecH $\mathrm{H}_{2}$ team for their support. 


\section{References}

[1] P.C. Hallenbeck, J.R. Benemann, Biological hydrogen production; fundamentals and limiting processes, Int. J. Hydrog. Energy. 27 (2002) 1185-1193.

[2] K. Schutz, T. Happe, O. Troshina, P. Lindblad, E. Leituo, P. Oliveira, P. Tamagnini, Cyanobacterial $\mathrm{H}_{2}$ production? A comparative analysis, Planta. 218 (2004) 350-359. doi:10.1007/s00425-003-1113-5.

[3] D.-J. Lee, K.-Y. Show, A. Su, Dark fermentation on biohydrogen production: Pure culture, Bioresour. Technol. 102 (2011) 8393-8402. doi:10.1016/j.biortech.2011.03.041.

[4] K.Y. Show, D.J. Lee, J.H. Tay, C.Y. Lin, J.S. Chang, Biohydrogen production: Current perspectives and the way forward, Int. J. Hydrog. Energy. 37 (2012) 15616-15631. doi:10.1016/j.ijhydene.2012.04.109.

[5] D. Levin, Biohydrogen production: prospects and limitations to practical application, Int. J. Hydrog. Energy. 29 (2004) 173-185. doi:10.1016/S0360-3199(03)00094-6.

[6] B.E. Logan, S.-E. Oh, I.S. Kim, S. Van Ginkel, Biological hydrogen production measured in batch anaerobic respirometers, Environ. Sci. Technol. 36 (2002) 25302535. doi:10.1021/es015783i.

[7] L. Cournac, F. Mus, L. Bernard, G. Guedeney, P. Vignais, G. Peltier, Limiting steps of hydrogen production in Chlamydomonas reinhardtii and Synechocystis PCC 6803 as analysed by light-induced gas exchange transients, Int. J. Hydrog. Energy. 27 (2002) 1229-1237.

[8] S. Fouchard, J. Pruvost, B. Degrenne, J. Legrand, Investigation of hydrogen production using the green microalga Chlamydomonas reinhardtii in a fully controlled photobioreactor fitted with on-line gas analysis, Int. J. Hydrog. Energy. 33 (2008) 33023310. doi:10.1016/j.ijhydene.2008.03.067.

[9] Z.A. Eltsova, L.G. Vasilieva, A.A. Tsygankov, Hydrogen production by recombinant strains of Rhodobacter sphaeroides using a modified photosynthetic apparatus, Appl. Biochem. Microbiol. 46 (2010) 487-491. doi:10.1134/S0003683810050042.

[10] L. Hakobyan, L. Gabrielyan, A. Trchounian, Yeast extract as an effective nitrogen source stimulating cell growth and enhancing hydrogen photoproduction by Rhodobacter sphaeroides strains from mineral springs, Int. J. Hydrog. Energy. 37 (2012) 6519-6526. doi:10.1016/j.ijhydene.2012.01.077.

[11] A. Teli, E. Ficara, F. Malpei, Biohydrogen production from cheese whey by dark fermentation, Chem. Eng. Trans. 37 (2014) 613-618. doi:10.3303/CET1437103.

[12] M. Badshah, D.M. Lam, J. Liu, B. Mattiasson, Use of an automatic methane potential test system for evaluating the biomethane potential of sugarcane bagasse after different $\begin{array}{lllll}\text { treatments, } & \text { Bioresour. } & \text { Technol. } & 114 & \text { (2012) }\end{array}$ doi:10.1016/j.biortech.2012.02.022.

[13] J.P. Donval, V. Guyader, Analysis of hydrogen and methane in seawater by headspace method: Determination at trace level with an automatic headspace sampler, Talanta. 162 (2017) 408-414. doi:10.1016/j.talanta.2016.10.034.

[14] R.J. Jones, J. Massanet-Nicolau, M.J.J. Mulder, G. Premier, R. Dinsdale, A. Guwy, Increased biohydrogen yields, volatile fatty acid production and substrate utilisation rates via the electrodialysis of a continually fed sucrose fermenter, Bioresour. Technol. 229 (2017) 46-52. doi:10.1016/j.biortech.2017.01.015.

[15] Y. Weijun, Analytical accuracy of hydrogen measurement using gas chromatography with thermal conductivity detection: Gas Chromatography, J. Sep. Sci. 38 (2015) 26402646. doi:10.1002/jssc.201500230.

[16] C. Boileau, R. Auria, S. Davidson, L. Casalot, P. Christen, P.-P. Liebgott, Y. CombetBlanc, Hydrogen production by the hyperthermophilic bacterium Thermotoga maritima 
part I: effects of sulfured nutriments, with thiosulfate as model, on hydrogen production and growth, Biotechnol. Biofuels. 9 (2016). doi:10.1186/s13068-016-0678-8.

[17] H. Atomi, T. Fukui, T. Kanai, M. Morikawa, T. Imanaka, Description of Thermococcus kodakaraensis sp. nov., a well studied hyperthermophilic archaeon previously reported as Pyrococcus sp. KOD1, Archaea. 1 (2004) 263-267.

[18] T.L. Miller, M.J. Wolin, A serum bottle modification of the Hungate technique for cultivating obligate anaerobes, Appl. Microbiol. 27 (1974) 985-987.

[19] B.E. Poling, J.M. Prausnitz, J.P. O'Connell, Properties of gases and liquids, Fifth Edition, McGraw-Hill Education: New York, Chicago, San Francisco, Athens, London, Madrid, Mexico City, Milan, New Delhi, Singapore, Sydney, Toronto, 2001.

[20] R. Sander, Compilation of Henry's law constants (version 4.0) for water as solvent, Atmospheric Chem. Phys. 15 (2015) 4399-4981. doi:10.5194/acp-15-4399-2015.

[21] J.P. Amend, E.L. Shock, Energetics of overall metabolic reactions of thermophilic and hyperthermophilic Archaea and Bacteria, FEMS Microbiol. Rev. 25 (2001) 175-243.

[22] N. Khanna, S.M. Kotay, J.J. Gilbert, D. Das, Improvement of biohydrogen production by Enterobacter cloacae IIT-BT 08 under regulated pH, J. Biotechnol. 152 (2011) 9-15. doi:10.1016/j.jbiotec.2010.12.014.

[23] T. de Vrije, M.A.W. Budde, S.J. Lips, R.R. Bakker, A.E. Mars, P.A.M. Claassen, Hydrogen production from carrot pulp by the extreme thermophiles Caldicellulosiruptor saccharolyticus and Thermotoga neapolitana, Int. J. Hydrog. Energy. 35 (2010) 1320613213. doi:10.1016/j.ijhydene.2010.09.014.

[24] E.W.J. van Niel, P.A.M. Claassen, A.J.M. Stams, Substrate and product inhibition of hydrogen production by the extreme thermophile, Caldicellulosiruptor saccharolyticus, Biotechnol. Bioeng. 81 (2003) 255-262. doi:10.1002/bit.10463.

[25] R. Auria, C. Boileau, S. Davidson, L. Casalot, P. Christen, P.P. Liebgott, Y. CombetBlanc, Hydrogen production by the hyperthermophilic bacterium Thermotoga maritima Part II: modeling and experimental approaches for hydrogen production, Biotechnol. Biofuels. 9 (2016). doi:10.1186/s13068-016-0681-0.

[26] T.A.D. Nguyen, J. Pyo Kim, M. Sun Kim, Y. Kwan Oh, S.J. Sim, Optimization of hydrogen production by hyperthermophilic eubacteria, Thermotoga maritima and Thermotoga neapolitana in batch fermentation, Int. J. Hydrog. Energy. 33 (2008) 14831488. doi:10.1016/j.ijhydene.2007.09.033.

[27] M. Ljunggren, K. Willquist, G. Zacchi, E.W. van Niel, A kinetic model for quantitative evaluation of the effect of hydrogen and osmolarity on hydrogen production by Caldicellulosiruptor saccharolyticus, Biotechnol. Biofuels. 4 (2011) 31. doi:10.1186/1754-6834-4-31.

[28] F.J. Millero, R.N. Roy, A chemical equilibrium model for the carbonate system in natural waters, Croat. Chem. Acta. 70 (1997) 1-38.

[29] R.N. Roy, L.N. Roy, K.M. Vogel, C. Porter-Moore, T. Pearson, C.E. Good, F.J. Millero, D.M. Campbell, The dissociation constants of carbonic acid in seawater at salinities 5 to 45 and temperatures 0 to $45^{\circ} \mathrm{C}$, Mar. Chem. 44 (1993) 249-267.

[30] W.J. Ward, W.L. Robb, Carbon dioxide--oxygen separation: facilitated transport of carbon dioxide across a liquid film, Science. 156 (1967) 1481-1484.

[31] T.E. Hoover, D.C. Berkshire, Effects of hydration on carbon dioxide exchange across an air-water interface, J. Geophys. Res. 74 (1969) 456-464. doi:10.1029/JB074i002p00456.

[32] J.A. Quinn, N.C. Otto, Carbon dioxide exchange at the air-sea interface: Flux augmentation by chemical reaction, J. Geophys. Res. 76 (1971) 1539-1549. doi:10.1029/JC076i006p01539. 


\section{List of figures}

Figure 1: Experimental system for the measurements in serum-bottle of the total pressure using a manometer gauge and the hydrogen content by gas chromatography. 1: water bath, 2 : syringe, 3: manometer, 4: anaerobic culture.

Figure 2: Partial pressure of $\mathrm{H}_{2}$ measured by gas chromatography versus total pressure of gas measured by the manometer for T. maritima.

Figure 3: Partial pressure of $\mathrm{H}_{2}$ measured by gas chromatography versus total pressure of gas measured by the manometer for T. kodakarensis.

Figure 4: Partial pressure of $\mathrm{H}_{2}$ measured by gas chromatography versus total pressure of gas measured by the manometer for E. cloacae.

Figure 5: Partial pressures of $\mathrm{H}_{2}$ and $\mathrm{CO}_{2}$ and, $\mathrm{pH}$ versus time: partial pressure of $\mathrm{H}_{2}(\mathrm{\circ})$, partial pressure of $\mathrm{CO}_{2}(\nabla)$ and $\mathrm{pH}(\square)$ with $\mathrm{BM} 1$; partial pressure of $\mathrm{H}_{2}(\bullet)$, partial pressure of $\mathrm{CO}_{2}(\boldsymbol{\nabla})$ and $\mathrm{pH}(\boldsymbol{\nabla})$ with $\mathrm{BM}$.

Figure 6: Partial pressure of $\mathrm{H}_{2}$ versus partial pressure of $\mathrm{CO}_{2}$ for T. maritima. (•) $\mathrm{BM}(\circ)$ BM1.

1. $\mathrm{H}_{2}=-0.84+2.09 \mathrm{CO}_{2}(\mathrm{R}=0.994) ;$ 2. $\mathrm{H}_{2}=0.33+2.65 \mathrm{CO}_{2}(\mathrm{R}=0.984)$ 


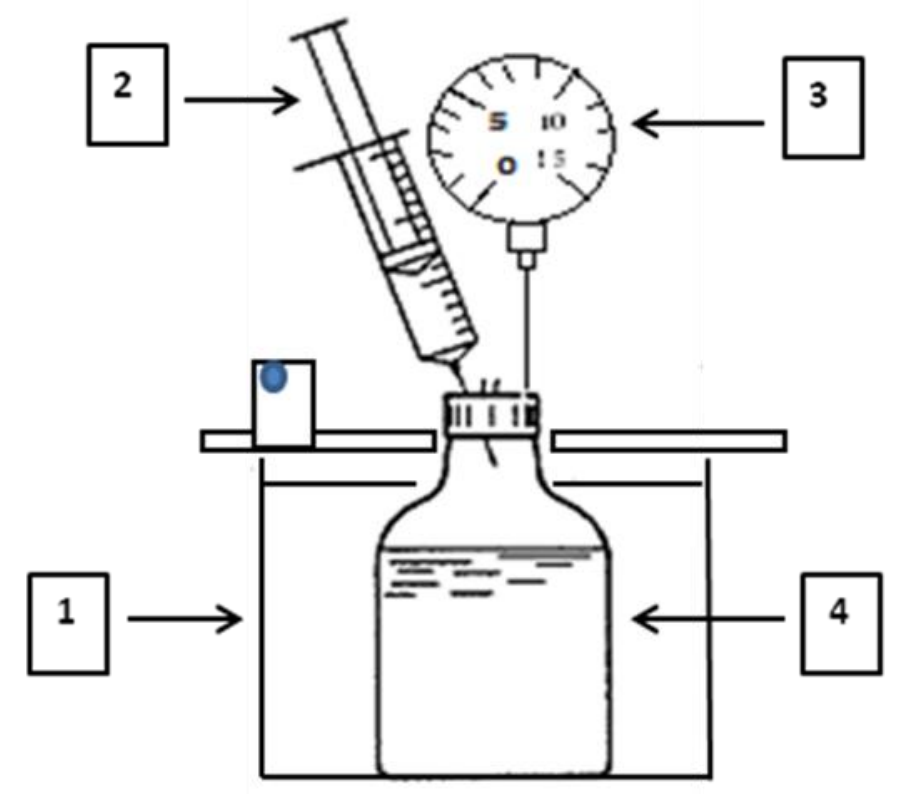

Figure 1

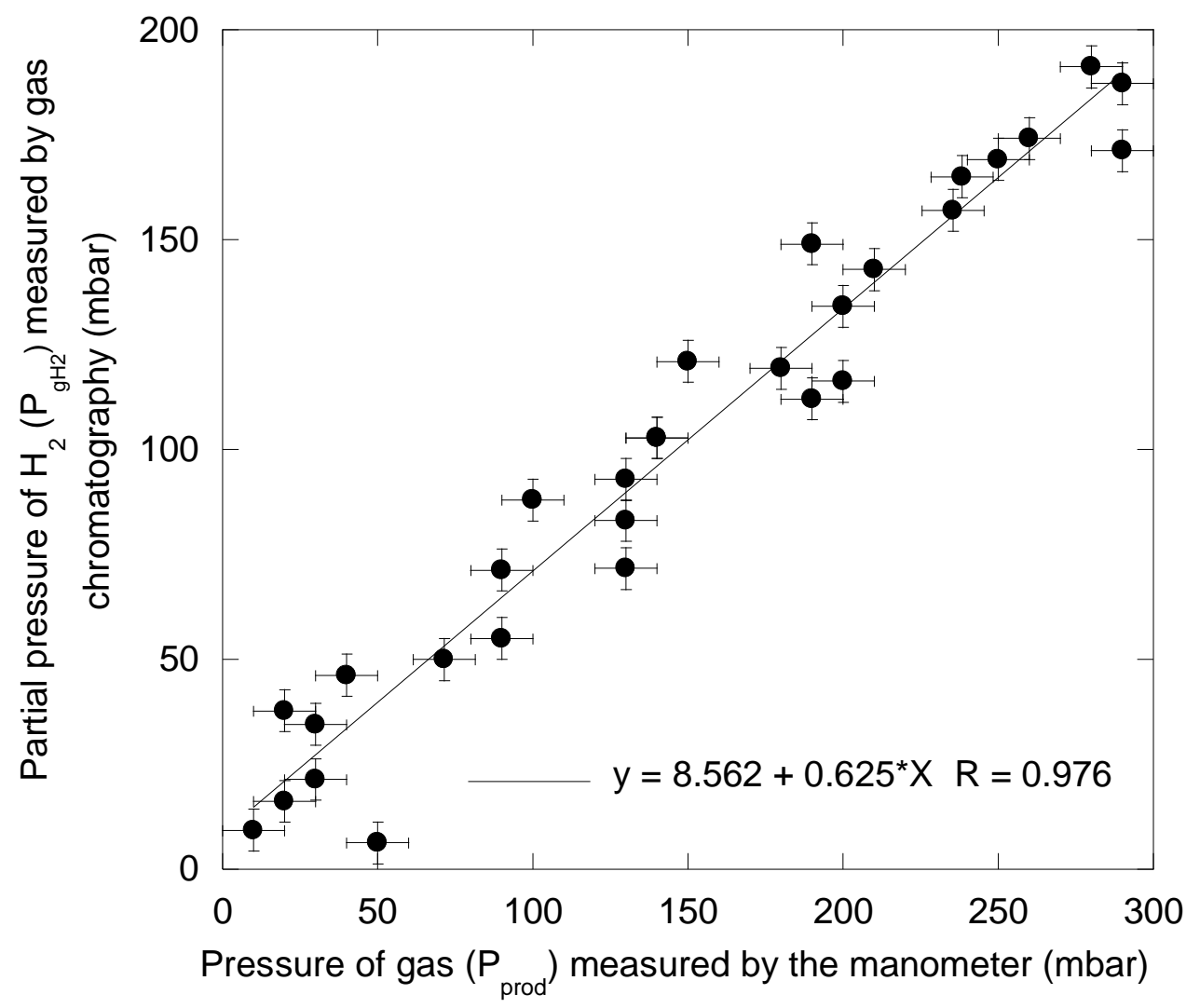

Figure 2 


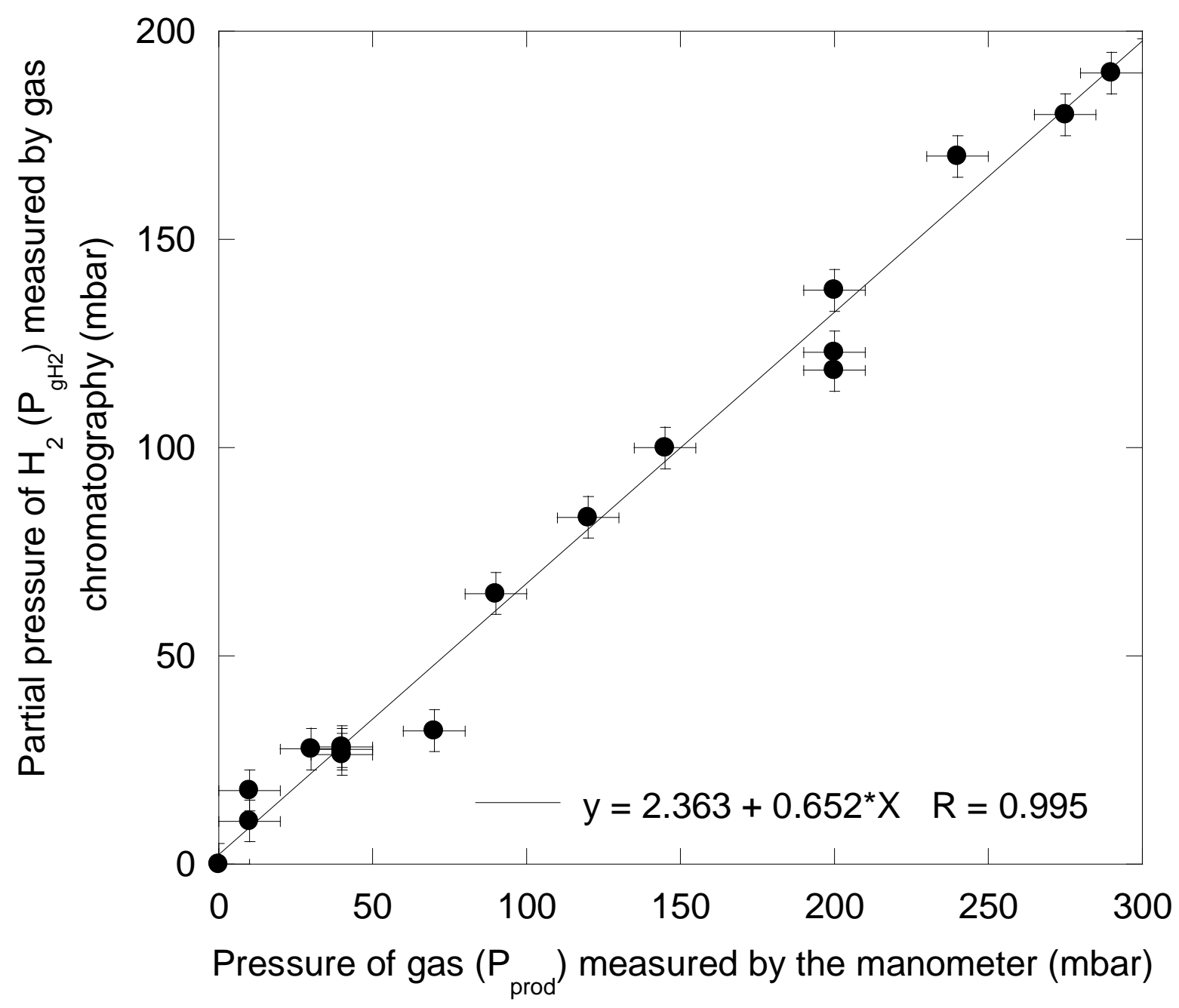

Figure 3 


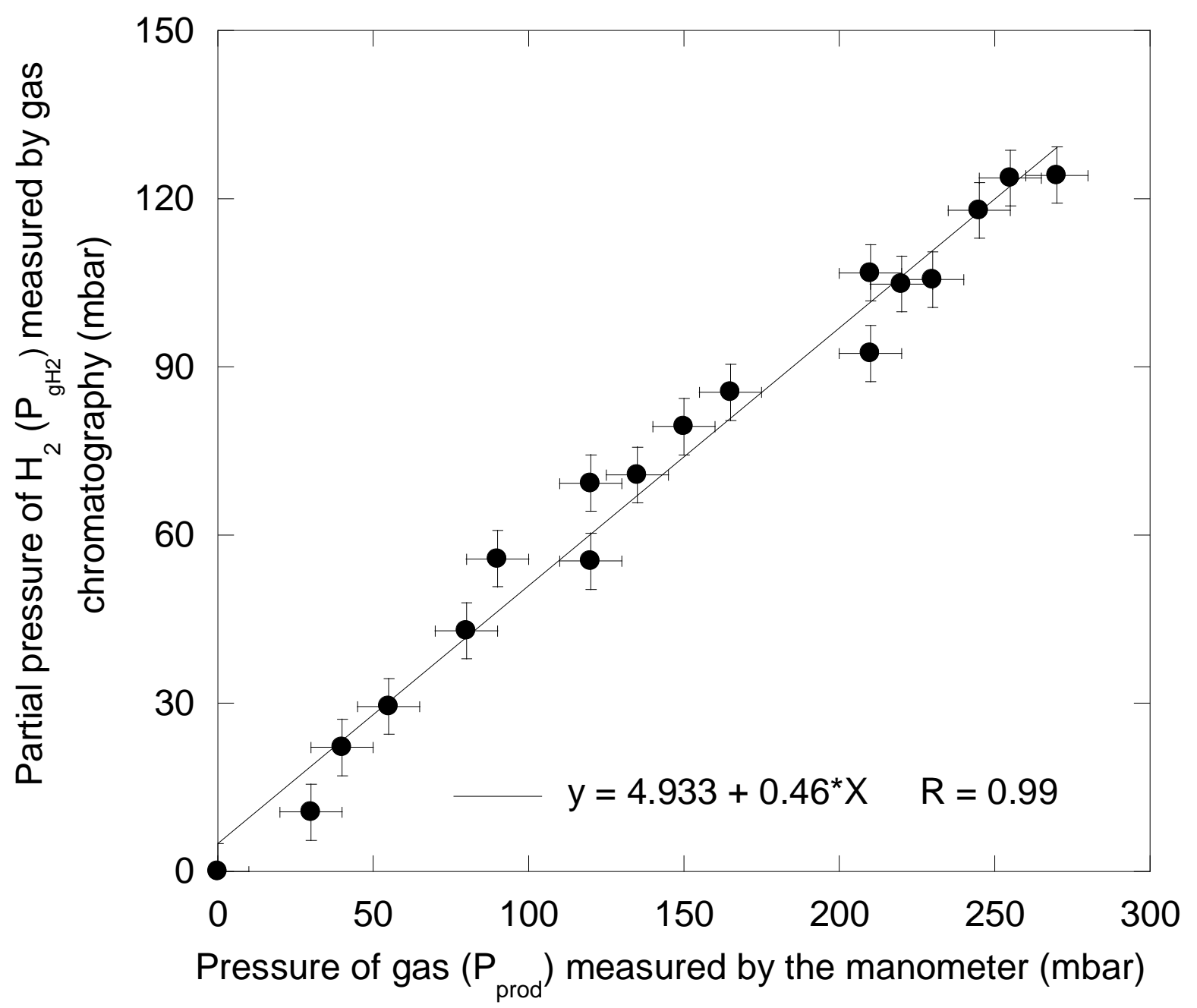

Figure 4 


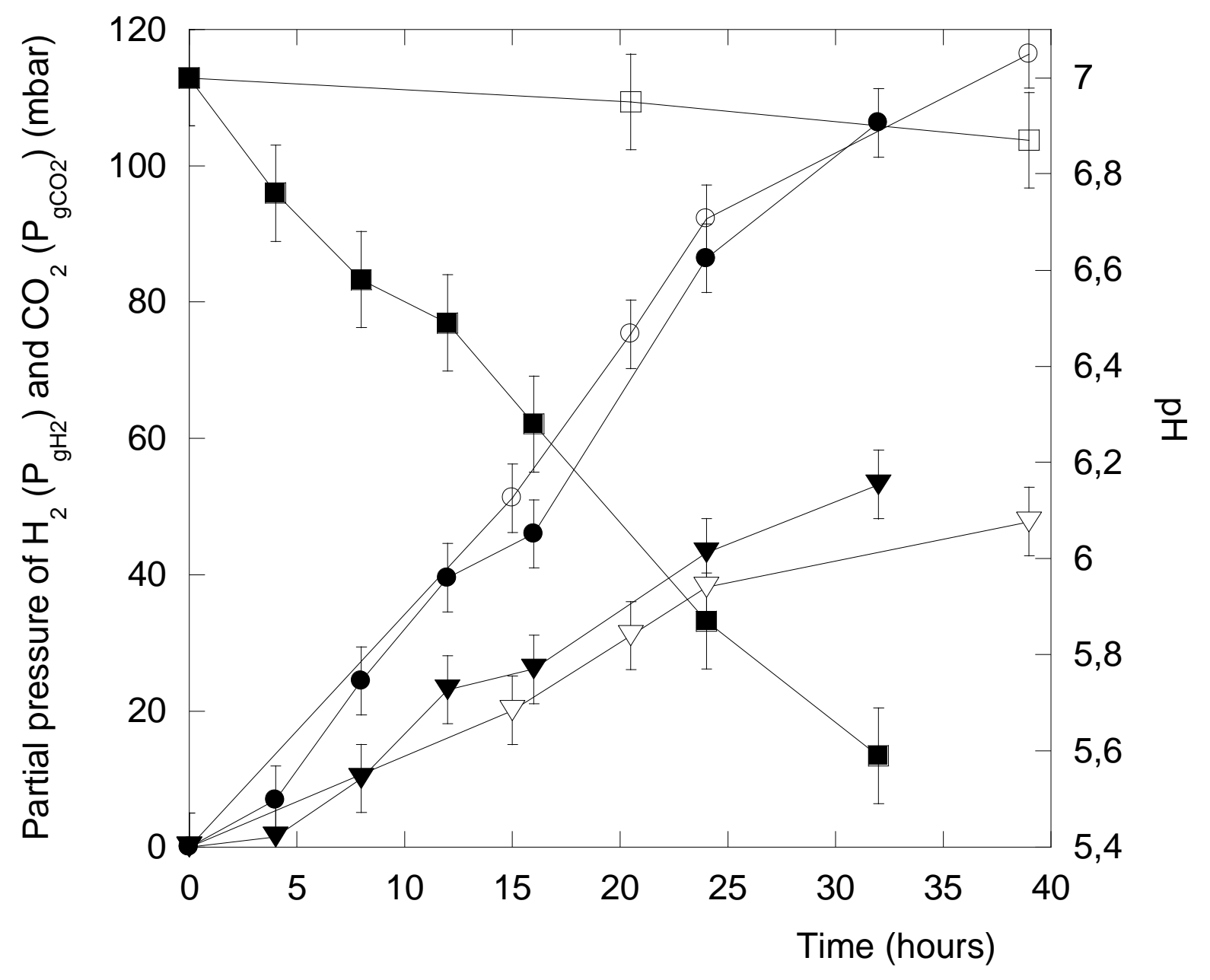

Figure 5 


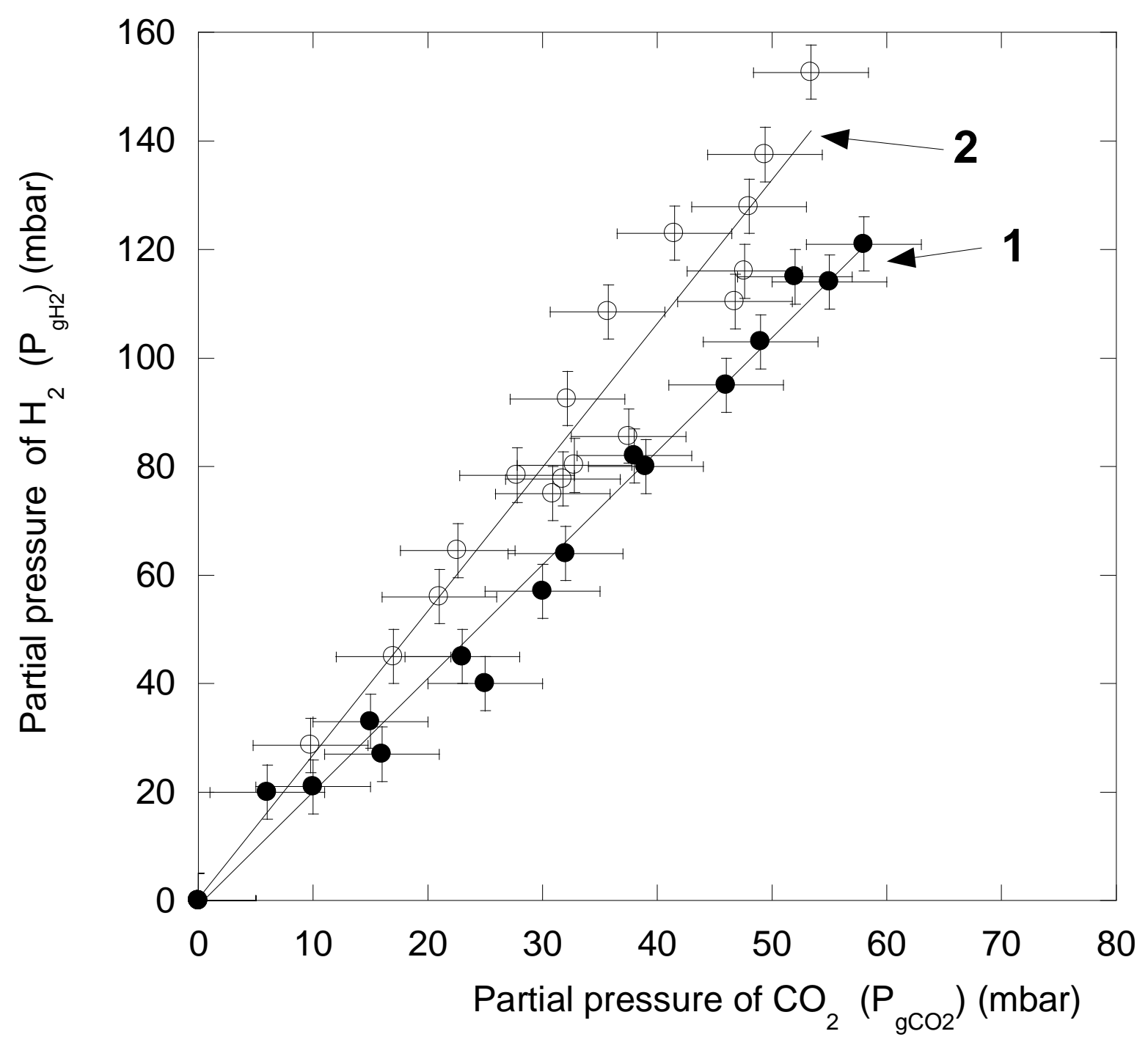

Figure 6 


\section{List of table}

Table 1: Saturation pressure of water $\left(\mathrm{P}_{\mathrm{vs}}\left(\mathrm{H}_{2} \mathrm{O}\right)\right)$ and pressure expansion of gases $\left(\mathrm{P}_{\exp }\right)$ versus temperature. $(*)$ calculated, $\left({ }^{* *}\right)$ measured.

Table 1

\begin{tabular}{|l|l|l|l|l|}
\hline $\mathrm{T}\left({ }^{\circ} \mathrm{C}\right)$ & $\begin{array}{c}\mathrm{P}_{\mathrm{vs}\left(\mathrm{H}_{2} \mathrm{O}\right)} \\
(\mathrm{mbar})\end{array}$ & $\begin{array}{c}\mathrm{P}_{\text {exp }} \\
(\mathrm{mbar})\end{array}$ & $\begin{array}{l}\mathrm{P}_{\mathrm{vs}\left(\mathrm{H}_{2} \mathrm{O}\right)}+\mathrm{P}_{\exp } \\
(\mathrm{mbar}))^{(*)}\end{array}$ & $\begin{array}{l}\mathrm{P}_{\mathrm{vs}\left(\mathrm{H}_{2} \mathrm{O}\right)}+\mathrm{P}_{\mathrm{exp}} \\
(\mathrm{mbar})\end{array}$ \\
\hline 35 & 55.9 & 51.8 & 107.7 & $100 \pm 10$ \\
\hline 70 & 308.5 & 185.1 & 493.6 & $500 \pm 10$ \\
\hline 80 & 468.4 & 207.3 & 675.7 & $680 \pm 10$ \\
\hline
\end{tabular}

